J. Braz. Chem. Soc., Vol. 18, No. 2, 384-390, 2007.

Printed in Brazil - (C2007 Sociedade Brasileira de Química

$0103-5053 \$ 6.00+0.00$

\title{
Chemical Modifications of Nimesulide
}

\author{
Sandhya Pericherla, Jyoti Mareddy, Geetha Rani D. P., Padmavathi V. Gollapudi and Sarbani Pal* \\ Department of Chemistry, MNR Post Graduate College, Kukatpally, Hyderabad, India
}

\begin{abstract}
As modificações químicas da nimesulida via $N$-acilação direta ou através de um processo em duas etapas, envolvendo redução do grupo nitro seguida da acilação/sulfonilação regiosseletiva da arilamina resultante são descritas. A etapa da acilação do segundo método foi mais rápida do que a acilação da nimesulida. Uma série de derivados $N$-acilados e $N$-sulfonilados de $N$-(4amino-2-fenóxi fenil)metanossulfonamida, obtidos a partir de nimesulida foram convenientemente preparados com bons a excelentes rendimentos. Alguns dos compostos sintetizados foram testados para inibição da ciclooxigenase e poucos mostraram seletividade para COX-2.
\end{abstract}

We describe here the chemical modifications of nimesulide either via direct $\mathrm{N}$-acylation or via a two-step process involving reduction of the nitro group followed by regioselective acylation/ sulfonylation of the resulting arylamine. The acylation step of the second approach was found to be faster than acylation of nimesulide. A number of $N$-acylated and $N$-sulfonylated derivatives of $\mathrm{N}$-(4-amino-2-phenoxy phenyl)methanesulfonamide obtained from nimesulide were conveniently prepared in good to excellent yields. Some of the compounds synthesized were tested for cyclooxygenase inhibition and few of them showed selectivity for COX-2.

Keywords: nimesulide, reduction, acylation, sulfonylation, COX-1, COX-2

\section{Introduction}

Therapeutic effects of commonly used anti-inflammatory agents such as NSAIDs (non-steroidal anti-inflammatory drugs) and COX-2 inhibitors are linked to the inhibition of the cyclooxygenase (COX) system. COX, catalyzes the first step of biosynthesis of prostanoids, exists in two isoforms e.g. a constitutive form called COX-1 responsible for physiological production of prostaglandins and an inducible form, known as COX-2, which is involved in the inflammation processes. ${ }^{1}$ Classical NSAIDs are nonselective inhibitor of COX. Therefore, their long-term use leads to the side effects particularly ulceration. After the discovery of second isoform, COX-2, its selective inhibition is considered as an alternative pharmacotherapeutic approach, which targets selective suppression of pathological processes at a therapeutic dosage without disturbing the normal production of physiologically necessary metabolites of arachidonic acid. Hence, the development of preferential COX-2 inhibitors was necessary and has been considered as a challenging task to improve benefit/risk ratio of NSAIDs. New drugs have been specifically designed to inhibit COX-2, which have

*e-mail: sarbani277@yahoo.com equal efficacy but significantly fewer gastrointestinal side effects than NSAIDs. The 1,2-diarylheterocycle having a sulfonamide $\left(-\mathrm{SO}_{2} \mathrm{NH}_{2}\right)$ or methylsulfone $\left(-\mathrm{SO}_{2} \mathrm{CH}_{3}\right)$ group attached at the $p$-position of any one of the aromatic rings is the frequently used chemical entity for the development of selective COX-2 inhibitors. This is exemplified by the development of celecoxib, ${ }^{2}$ rofecoxib, ${ }^{3}$ valdecoxib ${ }^{4}$ and its prodrug parecoxib sodium, ${ }^{5}$ etoricoxib ${ }^{6}$ and the most selective COX-2 inhibitor till today, lumiracoxib. ${ }^{7}$ Some of them have already entered either in the US or European market. Thus, identification and commercialization of these selective inhibitors, collectively called 'coxibs', is considered as a real breakthrough in the area of anti-inflammation research. Despite their grand commercial success, rofecoxib and valdecoxib were withdrawn recently due to its adverse cardiovascular side effects ${ }^{8}$ raising concerns regarding the safety of other coxibs. Interestingly, celecoxib, the first drug launched in the market is still in patient's use and it seems that there are perhaps striking differences among various COX-2 inhibitors concerning cardiovascular risk. Celecoxib is thought to exhibit markedly lower cardiovascular risk than rofecoxib, perhaps based on a lower COX-2/COX-1 selectivity ratio and the potential to improve endothelial function. 
However, it has been reported that some of the coxibs possessing sulfonamide moiety can inhibit carbonic anhydrase II. ${ }^{9}$ Hence new COX-2 inhibitors that are chemically different from the 1,2-diaryl class but at the same time possessing more enzyme specificity and less adverse side effects are required. The diaryl or aryl-heteroaryl ethers and thioethers are also known to be selective inhibitors of COX-2. This class of COX-2 inhibitors (Figure 1) includes $\mathrm{N}$-(4-nitro-2-phenoxy phenyl)methanesulfonamide or nimesulide (1) , NS-398 (2), flosulide (3), and L-745,337 (4). ${ }^{10-13}$ Nimesulide was introduced in 1985 and since then a large number of analogues have been synthesized by changing (i) the $\mathrm{R}$ group of the $\mathrm{NHSO}_{2} \mathrm{R}$ moiety, (ii) the substituent at C-2 position e.g. aryloxy group by arylsulfanyl group, (iii) the electron withdrawing group at the $\mathrm{C}-4$ position e.g. nitro by carboxy, ethoxycarbonyl, aminocarbonyl, cyano, aminosulfonyl or trifluoromethyl group and (iv) the central aryl ring by pyridine and pyridinium moiety. ${ }^{14-16}$ All the members of this class of COX-2 inhibitors can be represented by a general structure $\mathbf{8}$ as shown in the Figure 1 .

It was observed that when the electron withdrawing group was incorporated in the form of conformationally restricted cyclic ketones (see $\mathbf{3}$ and $\mathbf{4}$, Figure 1) and lactones (see 5, $\mathbf{6}$ and 7, Figure 1) some of them showed better COX-2 inhibiting properties and improved oral bioavailability. ${ }^{17}$ Interestingly, in all these cases the structure activity relationship (SAR) study focused on the several structural modifications maintaining the electron withdrawing group (EWG) directly attached at the C-4 position of the central aryl ring. We therefore, became interested in attaching the EWG one atom away from the $\mathrm{C}-4$ position and to study its subsequent effect on COX inhibition. Additionally, while the replacement of methyl group of $\mathrm{NHSO}_{2} \mathrm{CH}_{3}$ of nimesulide by a trifluoromethyl $\left(\mathrm{CF}_{3}\right)$ moiety has been reported, ${ }^{16}$ the role of acidic $\mathrm{NH}$ of methane sulfonamide moiety on anti-inflammatory activities, however, has not been studied extensively. Considering all these aspects and in continuation of our research on the development of novel anti-inflammatory agents we have prepared a number of chemically modified derivatives of nimesulide some of which showed interesting COX inhibiting properties. Our plan was to develop new COX-2 inhibitors other than "coxibs" with lower COX2/COX-1 selectivity ratio that might lead to better safety profile.

\section{Result and Discussion}

Our strategy to develop new COX inhibitors is based on the chemical modifications of nimesulide either via direct $N$-acylation or via a two-step process involving reduction of the nitro group followed by regioselective acylation/sulfonylation of the resulting arylamine. The synthesis of $\mathrm{N}$-acylated compounds of nimesulide (9a-b) is shown in Scheme 1. These acylation reactions were carried out under homogeneous reaction conditions employing acyl chlorides in pyridine at $25{ }^{\circ} \mathrm{C}$ to afford the desired products in good yields. The structure of all compounds synthesized was confirmed by spectroscopic methods.

The synthesis of $N$-acylated compounds $11 \mathrm{a}-11 \mathrm{~g}$ is shown in Scheme 2. $\mathrm{N}$-(4-amino-2-phenoxy phenyl) methanesulfonamide $\mathbf{1 0}$, a reduced form of nimesulide<smiles>COS(=O)(=O)c1ccc([N+](=O)[O-])cc1Oc1ccccc1</smiles>

1<smiles>COS(=O)(=O)c1cc2occ(N=O)c(=O)c2cc1Oc1ccccc1</smiles>

5<smiles>COS(=O)c1ccc([N+](=O)[O-])cc1OC1CCCCC1</smiles>

2

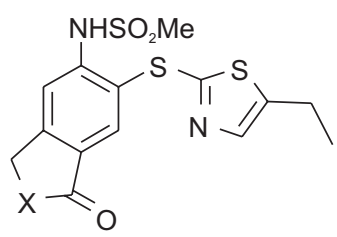

$6 \mathrm{X}=\mathrm{CH}_{2}$

$7 \mathrm{X}=\mathrm{O}$

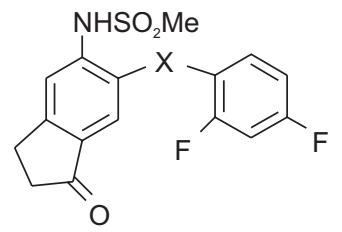

$3 x=0$

$4 \mathrm{X}=\mathrm{S}$

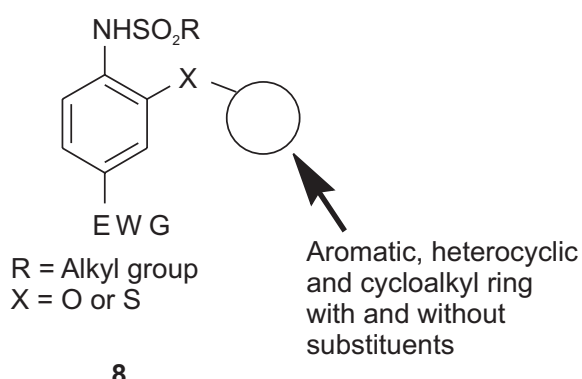

8

Figure 1. Examples of COX-2 inhibitors of diaryl or aryl heteroaryl ethers and thioethers. 


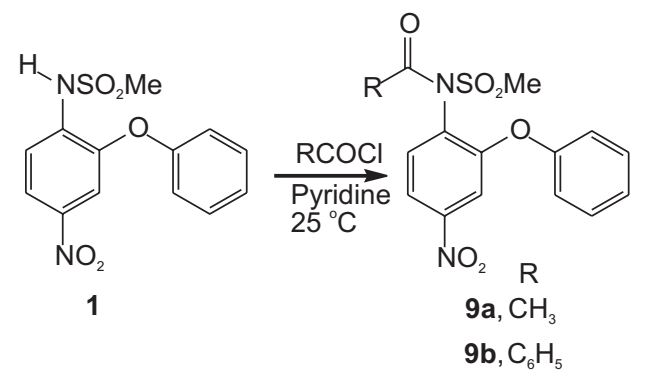

Scheme 1. Synthesis of $\mathrm{N}$-acylated derivatives of $4 \mathrm{~N}$-(4-amino-2-phenoxy phenyl)methanesulfonamide.

1 was efficiently prepared from $N$-(4-nitro-2-phenoxy phenyl)methanesulfonamide (nimesulide 1) by using $\mathrm{Sn}$ and $\mathrm{HCl}$. The reaction was carried out at $90^{\circ} \mathrm{C}$ for $3 \mathrm{~h}$ and the reduced product $\mathbf{1 0}$ was isolated in quantitative yield. The amino group of $\mathbf{1 0}$ was found to be highly reactive towards acylation and arylsulfonation reaction. Thus compound $\mathbf{1 0}$ was converted to the corresponding acylated or arylsulfonated derivative easily at room temperature as shown in Scheme 2. Results of our acylation and arylsulfonation reaction are listed in Table 1.

As indicated in Table 1 that acylation of nimesulide requires longer reaction time and higher temperature than its reduced form $\mathbf{1 0}$ (entries 1-2 vs. 3-9, Table1) where reaction took place at the free $\mathrm{NH}_{2}$ group instead of $\mathrm{NHSO}_{2} \mathrm{CH}_{3}$ moiety (see later for mechanistic discussion). A variety of acyl chlorides ( $\mathrm{RCOCl} ; \mathrm{R}=$ alkyl, aryl) were reacted with 10 and the acylated products 11a-g were isolated in good to excellent yield (72-91\%). These reactions were normally completed within 8-15 min irrespective of the acyl chlorides used (entries 3-9, Table 1). Yields of products were also found to be excellent when arylsulfonyl chlorides were reacted with $\mathbf{1 0}$ (entries 10 and 11, Table1). All the compounds synthesized were well characterized by ${ }^{1} \mathrm{H}$ NMR, IR and MS. In the IR spectra of all the compounds carbonyl-stretching bands of amide was seen in the region of $1650-1680 \mathrm{~cm}^{-1}$. In the ${ }^{1} \mathrm{H}$ NMR spectra $\mathrm{SO}_{2} \mathrm{CH}_{3}$ group appeared near $\delta 3.5 \mathrm{ppm}$.

We have carried out chemical modifications of nimesulide via direct acylation or via reduction followed by acylation/sulfonylation to afford a variety of analogues. Many of these compounds were tested against cyclooxygenase enzyme in vitro ${ }^{18}$ and all of them showed inhibitory effects especially against COX-2. Compound 11d and 12a showed 2 and 4 fold selectivity for COX-2 over COX-1 inhibition. At the concentration of $100 \mu \mathrm{mol}$ $\mathrm{L}^{-1}$ both the compounds showed $47 \%$ and $61 \%$ inhibition against COX-2 (with the standard deviation \pm 5.0 ). The moderate COX-2 selectivity shown by $\mathbf{1 1 d}$ and $\mathbf{1 2 a}$ could be beneficial as this might lead to the identification of COX-2 inhibitors with better safety profile. Interestingly, compound 11c was identified as nonselective inhibitor and compound 11e as COX-1 selective inhibitor (with the $\%$ inhibition noted as $51 \pm 7$ and $38 \pm 4$ at $100 \mu \mathrm{mol} \mathrm{L}-1$ against COX-1 and COX-2 respectively). Overall, the present study indicated that a new class of diaryl ethers could be generated via chemical modifications of nimesulide without affecting their COX inhibiting properties and COX-2 selectivity could be modulated via proper modifications.

Mechanistically, the acylation of nimesulide proceeds via generation of an anion from the methansulfonamide

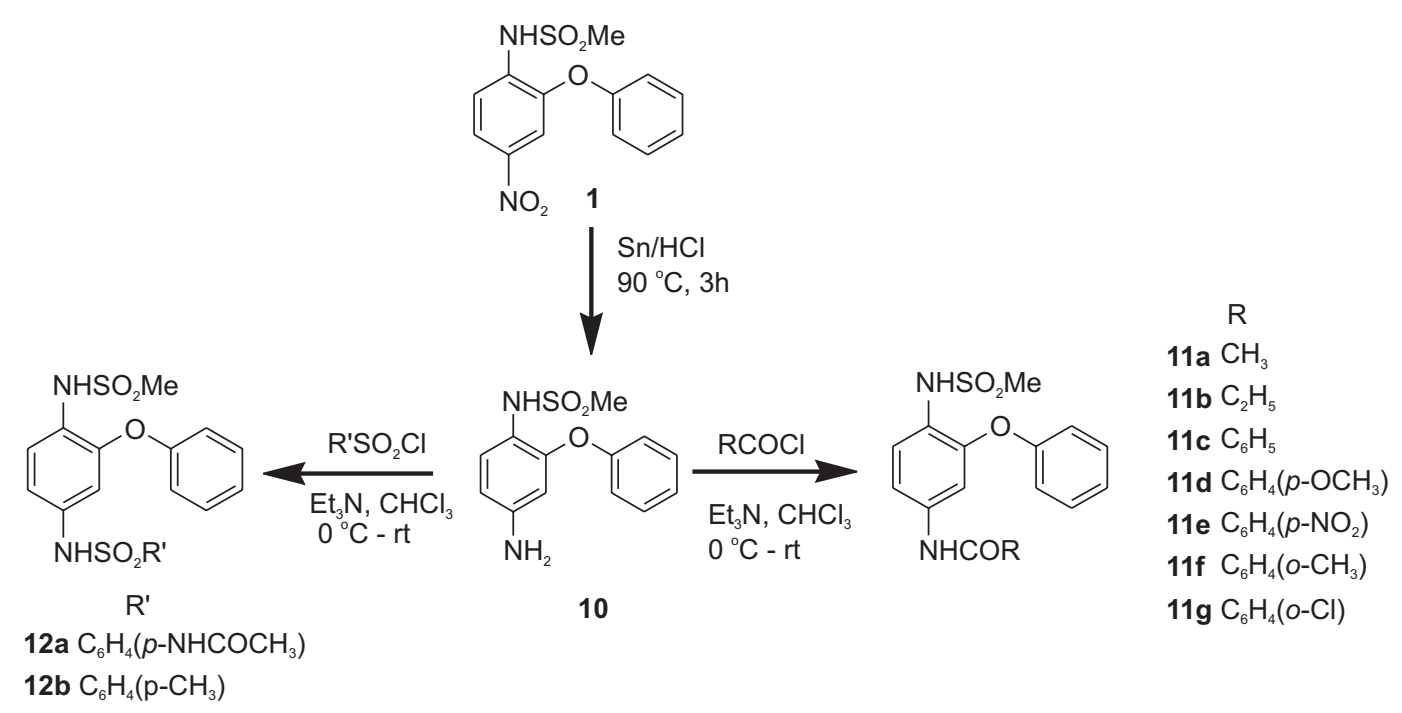

Scheme 2. Synthesis of $N$-acylated and $N$-sulfonylated derivatives of $N$-(4-amino-2-phenoxy phenyl)methanesulfonamide. 
Vol. 18, No. 2, 2007

Pericherla et al.

387

Table 1. Synthesis of $N$-acylated and $N$-sulfonylated $N$-(4-amino-2-phenoxy phenyl)methanesulfonamide and $N$-acylated nimesulide

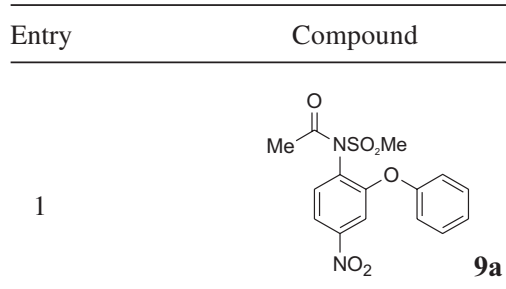

$4 \mathrm{~h}$

25

$6 \mathrm{~h}$
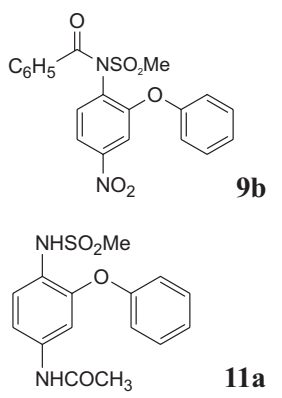

$11 \mathrm{a}$
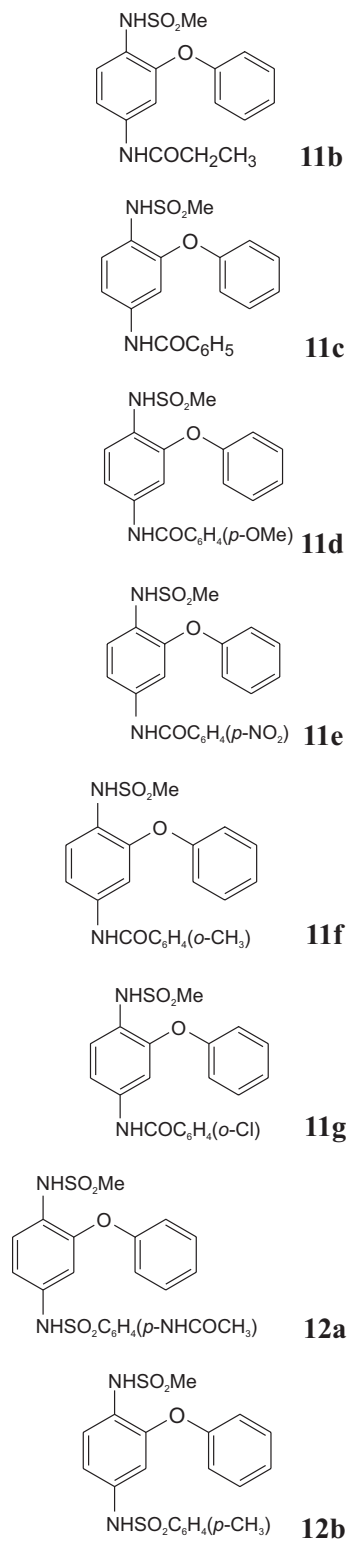

$9 \min$

$15 \mathrm{~min}$

$13 \mathrm{~min}$

$10 \mathrm{~min}$

0

0

0

$12 \mathrm{~min}$

0

0

91

0

72

$8 \min$

0

74

$9 \min$

0

94

$12 \min$

0

84 
moiety (i.e. $-\mathrm{N}^{-} \mathrm{SO}_{2} \mathrm{Me}$ ) followed by its subsequent nucleophillic attack on the carbonyl group of acyl chloride-pyridine complex generated in situ. This anion generation is facilitated due to the resonance stabilization of the resulting anion caused by the electron withdrawing nitro group. However, in case of compound $\mathbf{1 0}$ due to the higher reactivity of $\mathrm{NH}_{2}$ group over $\mathrm{NHSO}_{2} \mathrm{Me}$ moiety towards acylation/sulfonylation reaction it does not require generation of anion and therefore, participates in the reaction at lower temperature to afford $\mathbf{1 1}$ or $\mathbf{1 2}$. A further acylation or sulfonylation was not observed in case of $\mathbf{1 1}$ or $\mathbf{1 2}$ respectively due to the lack of resonance stabilization of the anion generated in these cases compared to that of nimesulide.

\section{Conclusions}

In conclusion we have described design and synthesis of a number of diaryl ether derivatives of potential biological significance via chemical modifications of a commonly used anti-inflammatory agent nimesulide. These derivatives were prepared from nimesulide either via direct $N$-acylation or via a two-step process involving reduction followed by regioselective acylation/ sulfonylation of the resulting compound $\mathbf{1 0} \mathrm{N}$-(4-amino2-phenoxy phenyl)methanesulfonamide. The acylation step of the second approach was found to be faster than acylation of nimesulide. The amino group was acylated or sulfonylated in case of $\mathbf{1 0}$ whereas $-\mathrm{NHSO}_{2} \mathrm{Me}$ moiety was acylated in case of nimesulide. A variety of $\mathrm{N}$-acylated and $\mathrm{N}$-sulfonylated derivatives of $\mathbf{1 0}$ were conveniently prepared for the first time in good to excellent yields. Some of the compounds synthesized showed moderate selectivity for COX-2 inhibition over COX-1 when tested against cyclooxygenase enzyme in vitro.

\section{Experimental}

\section{General methods}

Reactions were monitored by thin layer chromatography (TLC) on silica gel plates (60 F254), visualizing with ultraviolet light or iodine spray. Flash chromatography was performed on silica gel (60-120 mesh) using distilled petroleum ether and ethyl acetate. ${ }^{1} \mathrm{H}$ NMR spectra were determined in DMSO- $d_{6}$ solution on $200 \mathrm{MHz}$ spectrometers. Proton chemical shifts $(\delta)$ are relative to tetramethylsilane (TMS, $\delta=0.00$ ) as internal standard and expressed in ppm. Spin multiplicities are given as s (singlet), d (doublet) and $\mathrm{m}$ (multiplet) as well as b (broad). Coupling constants $(J)$ are given in hertz. Infrared spectra were recorded on a FT-IR spectrometer. Melting points were determined by using melting point apparatus and are uncorrected. MS spectra were obtained on a JMS-D 300 spectrometer. Elemental analyses were performed on a PerkinElmer 240C analyzer.

\section{Synthesis of 9}

To a stirred solution of nimesulide ( $3 \mathrm{~g}, 9.7 \mathrm{mmol})$, in dry pyridine $\left(0.5 \mathrm{~mol} \mathrm{~L}^{-1}\right.$ solution of substrate) was added freshly distilled acyl chloride ( 2 equiv.) at $25{ }^{\circ} \mathrm{C}$. The mixture was then stirred at $25{ }^{\circ} \mathrm{C}$ for $4-6 \mathrm{~h}$, poured into water $(20 \mathrm{~mL})$ and extracted with ethyl acetate $(3 \times 25$ $\mathrm{mL})$. Organic layers were collected, combined and dried over anhydrous $\mathrm{Na}_{2} \mathrm{SO}_{4}$ and concentrated. The crude solid was purified by column chromatography using ethyl acetate-xylene mixture and finally by recrystalisation from chloroform-xylene to afford the desired product.

\section{Synthesis of 11 and 12}

$\mathrm{N}$-(4-amino-2-phenoxy phenyl)methanesulfonamide (1 $\mathrm{g}, 3.56 \mathrm{mmol}$ ) was dissolved in dry chloroform and triethylamine $(0.6 \mathrm{~mL})$ was added to it. The solution was cooled to $0{ }^{\circ} \mathrm{C}$ and acyl chloride $(3.56 \mathrm{mmol})$ was added drop wise with stirring. The reaction mixture was then stirred at room temperature for 10-15 minutes, poured into water $(20 \mathrm{~mL})$ and extracted with chloroform $(3 \times 25$ $\mathrm{mL})$. Organic layers were collected, combined, washed with $10 \% \mathrm{HCl}(10 \mathrm{~mL})$ followed by water $(2 \times 10 \mathrm{~mL})$, dried over anhydrous $\mathrm{Na}_{2} \mathrm{SO}_{4}$ and concentrated. The residue was purified by re-crystallization from chloroformethyl acetate mixture.

\section{$N$-Acetyl-N-(4-nitro-2-phenoxy phenyl)methanesulfo- namide (9a)}

White solid; mp $119^{\circ} \mathrm{C}$; IR (KBr) $v_{\max } / \mathrm{cm}^{-1}: 1716$, 1586, 1531, 1487, 1354, 1234 and 1162; ${ }^{1} \mathrm{H}$ NMR (200 MHz, DMSO- $\left.d_{6}\right) \delta 8.02(\mathrm{dd}, J 8.8 \& 2.4 \mathrm{~Hz}, 1 \mathrm{H}), 7.7-7.1$ (m, 7H), $3.45(\mathrm{~s}, 3 \mathrm{H}), 2.12(\mathrm{~s}, 3 \mathrm{H})$; Mass $(\mathrm{m} / \mathrm{z}) 351\left(\mathrm{M}^{+}\right.$, $100 \%$ ); Elemental analysis found $\mathrm{C}, 51.62 ; \mathrm{H}, 4.12 ; \mathrm{N}$, 7.80; $\mathrm{C}_{15} \mathrm{H}_{14} \mathrm{~N}_{2} \mathrm{O}_{6} \mathrm{~S}$ requires C, 51.42; H, 4.03; N, 8.00.

\section{$N$-Benzoyl-N-(4-nitro-2-phenoxy phenyl)methanesulfo-} namide (9b)

White solid; mp $186{ }^{\circ} \mathrm{C}$; IR (KBr) $v_{\max } / \mathrm{cm}^{-1}: 1679$, 1549, 1530,1488, 1358, 1254 and 1166; ${ }^{1} \mathrm{H}$ NMR (200 MHz, DMSO- $\left.d_{6}\right) \delta 7.94(\mathrm{dd}, J 8.4 \& 2.4 \mathrm{~Hz}, 1 \mathrm{H}), 7.79(\mathrm{~d}$, $J$ 8.8 Hz), 7.5-7.2 (m, 8H), $6.68(\mathrm{~d}, J 5.5 \mathrm{~Hz}, 2 \mathrm{H}), 3.56(\mathrm{~s}$, $3 \mathrm{H})$; Mass $(\mathrm{m} / \mathrm{z}) 414\left(\mathrm{M}^{+}+1,100 \%\right)$; Elemental analysis found $\mathrm{C}, 58.48 ; \mathrm{H}, 3.76 ; \mathrm{N}, 6.97 ; \mathrm{C}_{20} \mathrm{H}_{16} \mathrm{~N}_{2} \mathrm{O}_{6} \mathrm{~S}$ requires C, 58.25; H, 3.91; N, 6.79 . 
$N$-(4-Amino-2-phenoxy phenyl)methanesulfonamide (10)

To a mixture of nimesulide ( $5 \mathrm{~g}, 16.2 \mathrm{mmol}$ ) and tin $(3.13 \mathrm{~g})$ was added conc. $\mathrm{HCl}(20 \mathrm{~mL})$ and the mixture was heated on a water bath at $90{ }^{\circ} \mathrm{C}$ for $3 \mathrm{~h}$. After the completion of the reaction the mixture was poured into ice water and the solid separated was filtered. After basification the crude product obtained was purified by re-crystallization from methanol and chloroform mixture to give the desired product as light brown solid; mp $198^{\circ} \mathrm{C}$; IR (KBr) $v_{\max } / \mathrm{cm}^{-1}: 3412,1572,1487,1215$ and 1154; ${ }^{1} \mathrm{H}$ NMR (200 MHz, DMSO- $\left.d_{\sigma}\right) \delta 9.2(\mathrm{~s}, 1 \mathrm{H}), 7.4$ $(\mathrm{m}, 2 \mathrm{H}), 7.3(\mathrm{~d}, J 8.6 \mathrm{~Hz}, 1 \mathrm{H}), 7.2(\mathrm{~m}, 2 \mathrm{H}), 6.8(\mathrm{~d}, J 8.6$ $\mathrm{Hz}, 1 \mathrm{H}), 6.5$ (s, 1H), 3.5 (br s, 2H), 3.1 (s, 3H); Mass $(\mathrm{m} / \mathrm{z}) 279.1\left(\mathrm{M}^{+}, 100 \%\right)$; Elemental analysis found $\mathrm{C}$, 56.25; H, 5.07; N, 10.26; $\mathrm{C}_{13} \mathrm{H}_{14} \mathrm{~N}_{2} \mathrm{O}_{3} \mathrm{~S}$ requires $\mathrm{C}, 56.10$; $\mathrm{H}, 5.07 ; \mathrm{N}, 10.06$.

$N$-(4-Methanesulfonylamino-3-phenoxy phenyl)-acetamide (11a)

White solid; mp $106{ }^{\circ} \mathrm{C}$; IR ( $\left.\mathrm{KBr}\right) v_{\max } / \mathrm{cm}^{-1}: 1673$, 1590; ${ }^{1} \mathrm{H}$ NMR (200 MHz, DMSO-d $) \delta 9.9$ (s, 1H), 9.2 (s, 1H), $7.41(\mathrm{~m}, 2 \mathrm{H}), 7.3$ (s, 2H), $7.2(\mathrm{~m}, 2 \mathrm{H}), 7.1$ (d, J $7.8 \mathrm{~Hz}, 2 \mathrm{H}), 2.9$ (s, 3H), 1.9 (s, 3H); Mass $(\mathrm{m} / \mathrm{z}) 321\left(\mathrm{M}^{+}\right.$, $100 \%$ ); Elemental analysis found C, 56.46; H, 5.17; N, 8.90; $\mathrm{C}_{15} \mathrm{H}_{16} \mathrm{~N}_{2} \mathrm{O}_{4} \mathrm{~S}$ requires $\mathrm{C}, 56.24 ; \mathrm{H}, 5.03 ; \mathrm{N}, 8.74$.

$N$-(4-Methanesulfonylamino-3-phenoxy phenyl) propionamide (11b)

Light brown solid; mp $136{ }^{\circ} \mathrm{C}$; IR $(\mathrm{KBr}) \mathrm{v}_{\max } / \mathrm{cm}^{-1}$ : 3318, 3264, 1654 and 1611; ${ }^{1} \mathrm{H}$ NMR (200 MHz, DMSO$\left.d_{6}\right) \delta 7.55(\mathrm{~d}, J 8.6 \mathrm{~Hz}, 1 \mathrm{H}), 7.39-7.10(\mathrm{~m}, 5 \mathrm{H}), 7.00(\mathrm{~d}, J$ $8.1 \mathrm{~Hz}, 2 \mathrm{H}), 6.67$ (s, 3H), 2.24 (q, J 7.5 Hz, 2H), 1.19 (t, $J 7.5 \mathrm{~Hz}, 3 \mathrm{H})$; Mass $(\mathrm{m} / \mathrm{z}) 335\left(\mathrm{M}^{+}, 100 \%\right)$; Elemental analysis found $\mathrm{C}, 57.41 ; \mathrm{H}, 5.26 ; \mathrm{N}, 8.53 ; \mathrm{C}_{16} \mathrm{H}_{18} \mathrm{~N}_{2} \mathrm{O}_{4} \mathrm{~S}$ requires $\mathrm{C}, 57.47 ; \mathrm{H}, 5.43 ; \mathrm{N}, 8.38$.

$N$-(4-Methanesulfonylamino-3-phenoxy phenyl) benzamide (11c)

Pale yellow solid; mp $170{ }^{\circ} \mathrm{C}$; IR (KBr) $v_{\max } / \mathrm{cm}^{-1}$ : $3328,3249,1655 ;{ }^{1} \mathrm{H}$ NMR (200 MHz, DMSO- $\left.d_{6}\right) \delta$ 7.8-7.0 (m, 14H), $6.7(\mathrm{~s}, 1 \mathrm{H}), 2.98(\mathrm{~s}, 3 \mathrm{H})$; Mass $(\mathrm{m} / \mathrm{z})$ $383.2\left(\mathrm{M}^{+}, 100 \%\right)$; Elemental analysis found $\mathrm{C}, 62.77$; $\mathrm{H}, 4.87 ; \mathrm{N}, 7.28 ; \mathrm{C}_{20} \mathrm{H}_{18} \mathrm{~N}_{2} \mathrm{O}_{4} \mathrm{~S}$ requires $\mathrm{C}, 62.81 ; \mathrm{H}$, 4.74; N, 7.33.

N-(4-Methanesulfonylamino-3-phenoxy phenyl)-4methoxybenzamide (11d)

White solid; mp $146{ }^{\circ} \mathrm{C}$; IR ( $\left.\mathrm{KBr}\right) v_{\max } / \mathrm{cm}^{-1}$ : 3316,1655, 1589; ${ }^{1} \mathrm{H}$ NMR (200 MHz, DMSO- $\left.d_{6}\right) \delta 10.12$ (s, 1H), 9.24 (s, 1H), 7.89 (d, J $8.8 \mathrm{~Hz}, 2 \mathrm{H}), 7.5$ (d, J 2.2 $\mathrm{Hz}, 1 \mathrm{H}), 7.46-7.01$ (m, 10H), 3.8 (s, 3H), 3.0 (s, 3H);
Mass $(\mathrm{m} / z) 412.5\left(\mathrm{M}^{+}, 100 \%\right)$; Elemental analysis found $\mathrm{C}, 61.36 ; \mathrm{H}, 4.95 ; \mathrm{N}, 6.86 ; \mathrm{C}_{21} \mathrm{H}_{20} \mathrm{~N}_{2} \mathrm{O}_{5} \mathrm{~S}$ requires $\mathrm{C}, 61.15$; H, 4.89; N, 6.79.

N-(4-Methanesulfonylamino-3-phenoxy phenyl)-4nitrobenzamide (11e)

Off white solid; mp $174^{\circ} \mathrm{C}$; IR (KBr) $v_{\max } / \mathrm{cm}^{-1}$ : 3306, 1648, 1588; ${ }^{1} \mathrm{H}$ NMR (200 MHz, DMSO-d $) \delta 10.5$ (s, $1 \mathrm{H}), 9.3(\mathrm{~s}, 1 \mathrm{H}), 8.3(\mathrm{~d}, J 8.5 \mathrm{~Hz}, 2 \mathrm{H}), 8.1(\mathrm{~d}, J 8.5 \mathrm{~Hz}$, 2H), 7.5 (dd, J 8.6 \& 2.4 Hz, 1H), 7.3- 7.0 (m, 3H), 2.9 (s, $3 \mathrm{H})$; Mass $(\mathrm{m} / \mathrm{z}) 428.1\left(\mathrm{M}^{+1}, 100 \%\right)$; Elemental analysis found $\mathrm{C}, 56.29 ; \mathrm{H}, 4.17 ; \mathrm{N}, 9.62 ; \mathrm{C}_{20} \mathrm{H}_{17} \mathrm{~N}_{3} \mathrm{O}_{6} \mathrm{~S}$ requires C, 56.20; H, 4.01; N, 9.83.

N-(4-Methanesulfonylamino-3-phenoxy phenyl)-2methylbenzamide (11f)

White solid; mp $122^{\circ} \mathrm{C}$; IR (KBr) $v_{\max } / \mathrm{cm}^{-1}: 3331$, 3255, 1659; ${ }^{1} \mathrm{H}$ NMR (200 MHz, DMSO- $d_{6}$ ) $\delta 10.3$ (s, 1H), $9.2(\mathrm{~s}, 1 \mathrm{H}), 7.0-7.8(\mathrm{~m}, 12 \mathrm{H}), 2.9(\mathrm{~s}, 3 \mathrm{H}), 2.2(\mathrm{~s}$, $3 \mathrm{H})$; Mass $(\mathrm{m} / \mathrm{z}) 397\left(\mathrm{M}^{+}, 100 \%\right)$. Elemental analysis found C, 63.76; H, 4.98; N, 7.21; $\mathrm{C}_{21} \mathrm{H}_{20} \mathrm{~N}_{2} \mathrm{O}_{4}$ S requires C, 63.62; H, 5.08; N, 7.07.

N-(4-Methanesulfonylamino-3-phenoxy phenyl)-2chlorobenzamide (11g)

Buff coloured solid; mp $76{ }^{\circ} \mathrm{C}$; IR $(\mathrm{KBr}) \mathrm{v}_{\max } / \mathrm{cm}^{-1}$ : 3293, 1651, 1603; ${ }^{1} \mathrm{H}$ NMR (200 MHz, DMSO- $\left.d_{6}\right) \delta 7.83$ (s, 1H), $7.71(\mathrm{~d}, J 7.3 \mathrm{~Hz}, 1 \mathrm{H}), 7.63(\mathrm{~d}, J 8.9 \mathrm{~Hz}, 1 \mathrm{H})$, 7.43-7.33 (m, 7H), $7.04(\mathrm{~d}, J 8.1 \mathrm{~Hz}, 1 \mathrm{H}), 6.72(\mathrm{~s}, 1 \mathrm{H})$, 2.9 (s, 3H); Mass $(\mathrm{m} / \mathrm{z}) 416\left(\mathrm{M}^{+}, 100 \%\right)$; Elemental analysis found $\mathrm{C}, 57.78 ; \mathrm{H}, 4.19 ; \mathrm{N}, 6.93 ; \mathrm{C}_{20} \mathrm{H}_{17} \mathrm{ClN}_{2} \mathrm{O}_{4} \mathrm{~S}$ requires $\mathrm{C}, 57.62 ; \mathrm{H}, 4.11 ; \mathrm{N}, 6.72$.

N-[4-(4-Methanesulfonylamino-3-phenoxy phenylsulfamoyl) phenyl] acetamide (12a)

White solid; mp $186^{\circ} \mathrm{C}$; IR (KBr) $v_{\max } / \mathrm{cm}^{-1}: 3231$, 3315, 1658, 1604; ${ }^{1} \mathrm{H}$ NMR (200 MHz, DMSO- $\left.d_{6}\right) \delta 9.87$ $(\mathrm{s}, 1 \mathrm{H}), 9.77(\mathrm{~s}, 1 \mathrm{H}), 8.17(\mathrm{~s}, 1 \mathrm{H}), 6.74-7.78(\mathrm{~m}, 12 \mathrm{H})$, $2.16(\mathrm{~s}, 3 \mathrm{H}), 2.89$ (s, 3H), $9.77(\mathrm{~s}, 1 \mathrm{H})$, Mass $(\mathrm{m} / \mathrm{z}) 476$ $\left(\mathrm{M}^{+}, 100 \%\right)$; Elemental analysis found $\mathrm{C}, 53.18 ; \mathrm{H}, 4.25$; $\mathrm{N}, 8.95 ; \mathrm{C}_{21} \mathrm{H}_{21} \mathrm{~N}_{3} \mathrm{O}_{6} \mathrm{~S}_{2}$ requires $\mathrm{C}, 53.04 ; \mathrm{H}, 4.45 ; \mathrm{N}$, 8.84 .

N-(4-Methanesulfonylamino-3-phenoxy phenyl]-4-methyl benzenesulfonamide (12b)

White solid; mp $142{ }^{\circ} \mathrm{C}$; IR (KBr) $v_{\max } / \mathrm{cm}^{-1}$ : 3331, 3230, 1659, 1590; ${ }^{1} \mathrm{H}$ NMR (200 MHz, DMSO- $\left.d_{6}\right) \delta 10.2$ (s, 1H), $9.2(\mathrm{~s}, 1 \mathrm{H}), 7.5-6.5(\mathrm{~m}, 12 \mathrm{H}), 2.9(\mathrm{~s}, 3 \mathrm{H}), 2.3(\mathrm{~s}$, $3 \mathrm{H})$; Mass $(\mathrm{m} / \mathrm{z}) 433\left(\mathrm{M}^{+}, 100 \%\right)$; Elemental analysis found $\mathrm{C}, 55.74 ; \mathrm{H}, 4.42 ; \mathrm{N}, 6.25 ; \mathrm{C}_{20} \mathrm{H}_{20} \mathrm{~N}_{2} \mathrm{O}_{5} \mathrm{~S}_{2}$ requires C, 55.54; H, 4.66; N, 6.48. 


\section{Acknowledgments}

The authors thank Mr. M. N. Raju, the chairman of M.N.R. Educational Trust for his constant encouragement and support. Authors also thank Professor B. C. Ranu, IACS, Kolkata for spectral support and Professor P. Reddanna and Mr. Anil of Hyderabad Central University, India for biological assays.

\section{References}

1. Xie, W.; Robertson, D. L.; Simmons, D. L. Drug Dev. Res. 1992, 25, 249; Vane, J. R.; Botting, R. M.; Am. J. Med. 1998, 104, 2S; Dewitt, D. L.; Mol. Pharmacol. 1999, 55, 625.

2. Penning, T. D.; Tally, J. J.; Bertenshaw, S. R.; Carter, J. S.; Collins, P. W.; Docter, S.; Graneto, M. J.; Lee, L. F.; Malecha, J. W.; Miyashiro, J. M.; Rogers, R. S.; Rogier, D. J.; Yu, S. S.; Anderson, G. D.; Burton, E. G.; Cogburn, J. N.; Gregory, S. A.; Koboldt, C. M.; Perkins, W. E.; Seibert, K.; Veenhuizen, A. W.; Zhang, Y. Y.; Isakson, P. C.; J. Med. Chem. 1997, 40, 1347.

3. Prasit, P.; Wang, Z.; Brideau, C.; Chan, C. C.; Charleson, S.; Cromilish, W.; Ethier, D.; Evans, J. F.; Ford-Hutchinson, A. W.; Gauthier, J. Y.; Gordon, R.; Guay, J.; Gresser, M.; Kargman, S.; Kennedy, B.; Leblanc, Y.; Leger, S.; Mancini, j.; O’Neill, G. P.; Ouellet, M.; Percival, M. D.; Perrier, H.; Riendeau, D.; Rodger, I.; Tagari, P.; Therien, M.; Vickers, P.; Wong, E.; Xu, L. -J.; Young, R. N.; Zamboni, R.; Boyce, S.; Rupniak, N.; Forrest, M.; Visco, D.; Patrick, D.; Bioorg. Med. Chem. Lett. 1999, 9, 1773; Ducharme, Y.; Gauthier, J. Y.; Prasit, P.; Lenlanc, Y.; Wang, Z.; Leger, S.; Therien, M.; World patent WO 95/ 00501, 1995; Chem. Abstr. 1996, 124, 55954y.

4. Tally, J. A.; Brown, D. L.; Carter, J. S.; Masferrer, M. J.; Perkins, W. E.; Rogers, R. S.; Shaffer, A. F.; Zhang, Y. Y.; Zweifel, B S.; Seibert, K.; J. Med. Chem. 2000, 43, 775.

5. Talley, J. J.; Bertenshaw, S. R.; Brown, D. L.; Carter, J. S.; Graneto, M. J.; Kellogg, M. S.; Koboldt, C. M.; Yuan, J.; Zhang, Y.Y.; Seibert, K.; J. Med. Chem. 2000, 43, 1661.

6. Friesen, R. W.; Brideau, C.; Chan, C. C.; Charleson, S.; Deschenes, D.; Dube, D.; Ethier, D.; Fortin, R.; Gauthier, J. Y.; Girard, Y.; Gordon, R.; Gauthier, J. Y.; Rien Deau, D.; Savoie, C.; Wang, Z.; Wong, E.; Visco, D.; Xu, L. -J.; Young, R. N.; Bioorg. Med. Chem. Lett. 1998, 8, 2777.

7. Berenbaum, F.; Grifka, J.; Brown, J. P.; Zacher, J.; Moore, A.; Krammer, G.; Dutta, D.; Sloan, V. S.; J. Int. Med. Res. 2005, 33, 21

8. Scheen, A. J.; Rev. Med. Liege 2004, 59, 565; Thompson, C. A.; Am. J. Health. Syst. Pharm. 2004, 61, 2234; Dogne, J-M.; Supuran, C. T.; Pratico, D.; J. Med. Chem. 2005, 48, 2251.

9. Weber, A.; Casini, A.; Heine, A.; Kuhn, D.; Supuran, C. T.; Scozzafava, A.; Klebe, G.; J. Med. Chem. 2004, 47, 550; Supuran, C. T.; Casini, A.; Mastrolorenzo, A.; Scozzafava, A.; Mini-Rev. Med. Chem. 2004, 4, 625.
10. Famaey, J. P.; Inflamm. Res. 1997, 46, 437; Davis, R.; Brogden, R.; Drugs 1994, 48, 431; Vigdahl, R. L.; Tukey, R. H.; Biochem. Pharmacol. 1977, 26, 307. Swingle, K. F.; Moore, G. G. I.; Drugs Exp. Clin. Res. 1984, 10, 587; Cullen, L.; Kelly, L.; Connor, S. O.; Fitzgerald, D. J.; J. Pharmacol. Exp. Ther. 1998, 287, 578.

11. Shah, A. A.; Murray, F. E.; Fitzgerald, D. J.; Rheumatology 1999, 38, 19; Futaki, N.; Takahashi, S.; Yokoyama, M.; Arai, I.; Higuchi, S.; Otomo, S.; Prostaglandins 1994, 47, 55; Huff, R.; Collns, P.; Kramer, S.; Seibert, K.; Loboldt, C.; Gregory, S.; Isakson, P.; Inflammation Res. 1995, 44, S145.

12. Chan, C. C.; Black, C.; Boyce, S.; Brideau, C.; FordHutchinson, A. W.; Gordon, R.; Guay, J.; Hill, R.; Li, C.S.; Mancini, J.; Penneton, M.; Prasit, P.; Rasori, R.; Riendeau, D.; Roy, P.; Tagari, P.; Vickers, P.; Wong, E.; Rodger, W.; J. Pharmacol. Exp. Ther. 1995, 274, 1531.

13. Swingle, K. F.; Hamilton, R.R.; Harrington, J.K.; Kvam, D.C.; Arch. Int Pharmacodyn. Ther. 1971, 189, 129; Scheigetz, J.; Zamboni, R.; Roy, B.; Synth. Commun. 1995, 25, 2791; Riendeau, D.; Charleson, S.; Cromlish, W.; Mancini, J. A.; Wong, E.; Guay, J.; Can. J. Physiol. Pharmacol. 1997, 75, 1088; Li, C.-S.; Black, W. C.; Chan, C.-C.; Ford-Hutchinson, A. W.; Gauthier, J.-Y.; Gordon, R.; Guay, D.; Kargman, S.; Lau, C. K.; Mancini, J.; Ouimet, N.; Roy, P.; Vickers, P.; Wong, E.; Young, R. N.; Zamboni, R.; Prasit, P.; J. Med. Chem. 1995, 38, 4897.

14. Tsuji, K.; Nakamura, K.; Konishi, N.; Okumura, H.; Matsuo, M.; Chem. Pharm. Bull. 1992, 40, 2339.

15. Blaschke, H.; Kremminger, P.; Hartmann, M.; Fellier, H.; Berg, J.; Christoph, T.; Rovensky, F.; Stimmeder, D.; PCT Int. Appl. WO 97 03953, Chem. Abstr. 1997, 126, 199339.

16. Julémont, F.; Leval, de X.; Michaux, C.; Renard, J.F.; Winum, J.-Y.; Damas, J.; Charlier, C.; Durant, F.; Pirotte, B.; Leval, de X.;. J. Med. Chem. 2002, 45, 5152; Julémont, F.; Leval, de X.; Michaux, C.; Renard, J.F.; Winum, J.-Y.; Montero, J. -L.; Damas, J.; Dogné, J. -M.; Pirotte, B.; J. Med. Chem. 2004, 47, 6749; Michaux, C.; Charlier, C.; Julémont, F.; Leval, de X.; Dogné, J. -M.; Pirotte, B.; Durant, F.; Eur. J. Med. Chem. 2005, 40, 1316 and references cited therein.

17. Guay, D.; Li, C.S.; Ouimet, N.; PCT Int. Appl.WO 9623786 , Chem. Abstr. 1996, 125, 221839.

18. Enzyme activity was measured using a chromogenic assay based on oxidation of $N, N, N^{\prime}, N^{\prime}$-tetramethyl- $p$-phenylenediamine (TMPD) during the reduction of $\mathrm{PGG}_{2}$ to $\mathrm{PGH}_{2}$ according to the procedure reported in the literature, see Copeland, R. A.; Williams, J. M.; Giannaras, J.; Nurnberg, S.; Covington, M.; Pinto, D.; Pick, S.; Trzaskos, J. M.; Proc. Natl. Acad. Sci. USA 1994, 91, 11202.

Received: September 12, 2006 Web Release Date: March 23, 2007 